Author's version. Please see the version of record, published in Poff, D. C. \& Michalos, A. C. (Eds.) Encyclopedia of Business and Professional Ethics. Springer. Available at: https://doi.org/10.1007/978-3-319-23514-1_1259-1

\title{
MacIntyre and Business Ethics
}

\author{
Matthew Sinnicks
}

\section{INTRODUCTION}

Scottish philosopher Alasdair C. MacIntyre (1929- ) is the most widely cited virtue ethicist in the business ethics literature (Ferrero \& Sison, 2014). This is somewhat surprising, given MacIntyre's own hostility to business. According to MacIntyre, our economic and social order is fundamentally compartmentalised (1999a), and we inhabit an emotivist culture in which ethical discourse is largely an expression of untutored feeling (2007). In light of this he has suggested that the problems of business ethics are insoluble (1982), that management is inherently amoral (2007), and that business ethics courses are a waste of time (2015). Despite such claims, and the obvious relevance of his critique of management, the radical nature of MacIntyre's thought is taken up relatively rarely in the business ethics literature (though see Couch \& Bernacchio 2020, Sinnicks 2021). The following discussion begins with a summary of this critique of management before going on to explore the aspect of MacIntyre's work which has had the greatest influence in business ethics, his account of practices and institutions in After Virtue (2007 [original publication 1981]). It then concludes with an overview of the relevance of MacIntyre's more recent work for business ethics.

\section{CRITIQUE OF MANAGEMENT}

MacIntyre suggests that contemporary social life can be understood as a drama in which certain characters - the therapist, the rich aesthete, and the manager - play leading roles. These characters, suggests MacIntyre, provide our "culture with its moral definitions" (2007, p.31). Unlike ordinary occupational roles, these characters "place a certain kind of moral constraint on the personality of those who inhabit them" (MacIntyre 2007, p.27). Of the three contemporary characters MacIntyre identifies, he regards the manager as especially important. He claims that

\footnotetext{
the manager represents in his character the obliteration of the distinction between manipulative and non-manipulative social relations ... The manager treats ends as given, as outside his scope; his concern is with technique, with effectiveness in transforming raw materials into final products, unskilled labor into skilled labor, investment into profits. $(2007$, p.30)
}

Because of this, the manager is incapable of genuine moral engagement, and is instead an embodiment of emotivism, the 'boo-hurrah' theory of moral meaning according to which statements of moral praise and blame are nothing other than expressions of subjective feeling. On this view, to say ' $\mathrm{X}$ is wrong' is simply to say, 'I dislike $\mathrm{X}$, do so as well'. Hence, the obliteration of the distinction between manipulative and non-manipulative social relations: all methods of bringing someone to disapprove of $\mathrm{X}$ are equally legitimate, according to this view. 
This status as inherently manipulative is not a matter of individual failing, it is instead an essential feature of the managerial role and thus aligned with the self-understanding of management. Managers

are seen by themselves, and by those who see them with the same eyes as their own, as uncontested figures, who purport to restrict themselves to the realms in which rational agreement is possible - that is, of course from their point of view to the realm of fact, the realm of means, the realm of measurable effectiveness. $(2007$, p.30)

According to MacIntyre, such a separation of means from ends gives management a distinctively Weberian flavour. This is because it allows management to understand and present itself as calculating ever more exact means by which to achieve the pre-set end of profit in line with Weber's account of bureaucratic rationality. On this view ends are not open to rational evaluation, only means are, and bureaucratic experts - managers - are charged with devising and implementing these rational means.

However, MacIntyre regards this bureaucratic expertise as impossible and suggests that attempts to successfully formulate lawlike generalisations in the social sciences, of the kind required to support any claim to bureaucratic expertise, are bound to fail. He notes that

given the best possible stock of generalizations, we may on the day be defeated by an unpredicted and unpredictable counter-example - and yet still see no way to improve our generalizations and still have no reason to abandon them or even reformulate them. (2007, p.93)

Few would seek to defend management on the grounds that it is based on knowledge of lawlike generalisations in the social sciences. Many, including many impressed by MacIntyre's broader body of work, would defend management on the grounds that it can, and often does, avoid collapsing into mere manipulativeness. For example, while Moore suggests that it "seems clear that the basic tenets of [MacIntyre's] position, at least in respect of managers in business organisations under Anglo-American capitalism, remain in place" (2008, p.495), he nevertheless concludes that MacIntyre's argument for the amorality of management is incorrect: "Are managers simply the morally-neutral efficient achievers of predetermined ends? Clearly... the answer is no" (2008, p.505). While it may be the case that value-laden management - and leadership - remain susceptible to the charge of emotivism (see Sinnicks 2018), Moore's reason for this judgement is that on his view - and contrary to MacIntyre's own - management, properly conceived of, is a practice. This concept of practices is at the core of MacIntyre's understanding of good work, and indeed serves as a foundation for his account of the ethical life.

\section{PRACTICES AND INSTITUTIONS}

MacIntyre's thought reserves an important place for the concept of good work. Indeed, he claims that we "ought to eat in order to work, not vice versa. The classical expression of this view is Aristotle's, but all artists, most professors and some socialists believe it too" (1979, p.44). His more detailed and influential discussion of good work occurs in his account of practices, the first of three states - along with narrative unity of a human life and traditions of enquiry - of his definition of virtues. To engage in a practice requires us to acquire and exercise the virtues, and indeed some virtues are required by all practices. For instance, we require 
courage to open ourselves up to the criticisms of other practitioners, justice to ensure that each contribution to the practice is suitably recognised, and so on.

It is worth noting that MacIntyre uses the word 'practice' in a highly specific way:

By a 'practice' I am going to mean any coherent and complex form of socially established cooperative human activity through which goods internal to that form of activity are realized in the course of trying to achieve those standards of excellence which are appropriate to, and partially definitive of, that form of activity, with the result that human powers to achieve excellence, and human conceptions of the ends and goods involved, are systematically extended. (2007, p.187)

This definition has been central to contributions in business ethics which draw on MacIntyre's work, as such contributions often take the form of arguments in favour of certain forms of work being worthy of the status of practices. The key aspect here is the notion of goods internal to practice. These are goods which cannot be achieved in any way other than by engaging in the activity in question. MacIntyre provide a variety of examples of practices. They include architecture, chess, portrait painting, physics, football and farming. Examples of non-practices include bricklaying, throwing or kicking a ball with skill, and turnip planting (2007, p.187). According to MacIntyre, to

enter into a practice is to enter into a relationship not only with contemporary practitioners, but also with those who have preceded us in the practice... Practices never have a goal or goals fixed for all time - painting has no such goal nor has physics - but the goods themselves are transmuted by the history of the activity. (2007, p.194)

Clearly then, practice engagement involves intellectual discovery, requires commitment and creativity, and the historical mediation foreshadows MacIntyre's discussion of tradition-based enquiry (see 2007, ch.15). Indeed, MacIntyre is keen to highlight the role of the relevant community for those who engage in practices. He says, "whether we are painters or physicists or quarterbacks or indeed just lovers of good painting or first-rate experiments or a well thrown pass", we must subordinate "ourselves within the practice in our relationship to other practitioners" (2007, p. 191). This admission of peripheral practitioners - lovers of well-thrown passes as well as those who play with excellence - is telling, and expands the scope of practices considerably. However, it also highlights the importance of proper motivation, as it allows that the devoted admirer of, say, football, can experience the relevant internal goods more meaningfully than the skilled, but entirely extrinsically motivated, player.

This issue of extrinsic motivation takes us on to another important aspect of MacIntyre's discussion of practices, particularly as it relates to business ethics: how practices relate to institutions. Institutions pursue external goods - money, fame, power - rather than internal goods. Practices thus need institutions if they are to survive - tennis needs tennis clubs, fields of enquiry need schools and universities. However, they are also threatened by institutional acquisitiveness. It is this interplay that is at the heart of much research in business ethics that draws on MacIntyre's work (see, in particular, Moore and Beadle 2006).

However, MacIntyre also notes that "the making and sustaining of forms of human community - and therefore of institutions - itself has all the characteristics of a practice" (2007, p.194). This practice MacIntyre names politics, in its Aristotelian sense. While the challenge of institutional domination, along with the critique of management outlined above, should make us wary of drawing too optimistic a picture of management from MacIntyre's work, this point 
allows us to conceive of managers as being engaged in a practice, politics. Furthermore, the expanded understanding of practice-engagement helps us to see how managers may be partially engaged in the practice their organisation houses, even if it is worth remembering that MacIntyre continues to beliee that the "practice of the virtues...is something difficult to reconcile with functioning well in the present economic order" (MacIntyre 2008, p.6).

\section{BEYOND AFTER VIRTUE}

Given the pre-eminence of After Virtue within MacIntyre's oeuvre, as well as the obvious relevance of his critique of management and his account of practices, it is unsurprising that it has dominated MacIntyrean contributions within business ethics. Nevertheless, there is much in MacIntyre's work since that is relevant to our attempts to navigate the ethical challenges presented by work, capitalism, and commercial life, even though this has been perhaps underexplored in the business ethics literature.

MacIntyre (1999a) argues that role-structured activity, of the sort required by much contemporary work, undermines moral agency because it forces us to compartmentalise the different and competing demands of the various roles we hold. This compartmentalisation prevents us from adequately perceiving the conflicts that exist between our professional and personal lives because we are unable to achieve a role-transcendent evaluation of those demands.

One noteworthy application of MacIntyre's more recent work has been developed by Bernacchio (2018), who draws extensively on MacIntyre's Dependent Rational Animals (1999b). In this work, MacIntyre corrects the non-metaphysical conception of ethics advanced in After Virtue by reflecting on the reality of human vulnerability, and extends his "account of practices, institutions, and communities by illustrating the indispensability of uncalculating relationships that are sustained by virtues that serve to direct agents toward the needs of others" (Bernacchio 2018, p.380), which Bernacchio then explores with reference to cooperation between members of ostensibly competing organisations in the garment industry.

MacIntyre (2015) addresses the ethics of finance, and argues that it is incompatible with four habits that are necessary for proper moral agency: an ability to properly appraise one's own talents, an ability to distinguish between reasonable and foolhardy risks, a commitment to the common good, and the habit of focusing neither "on the present at the expense of the future nor on the future at the expense of the present" (2015, p.10). MacIntyre (2015) also takes issue with the view that judicious reforms to business ethics curricula could lead to a significant improvement in how finance is practiced: the study of business ethics, thinks MacIntyre, "is a dangerous distraction" $(2015, \mathrm{p} .8)$. The argument MacIntyre offers here has been challenged by Rocchi et al. (2021), who appeal to the ways in which finance can contribute to the creation of various common goods.

In his most recent major work, Ethics in the Conflicts of Modernity (2016), MacIntyre suggests that we need to learn key truths "about the destructive and self-destructive aspects of capitalism" from Marx (2016, p.97), that militant trade union action is a pre-requisite for even "elementary justice" in contemporary society (2016, p.107), and that market societies such as ours must treat the vice of acquisitiveness as a virtue (2016, p.109). However, just as with After Virtue, where his account of practices and institutions gives us grounds for both a critique of 
work in contemporary society as well as hope about our ability to find community and engage in meaningful and good work within this society, MacIntyre (2016) also provides resources that might underpin more constructive work in business ethics. In particular, MacIntyre acknowledges that, while rare, it is still possible to find contemporary work in such good order that "[m]ore experienced workers become teachers. Managers become enablers" (2016, p.132).

This affirmative comment on management is coupled with an approving discussion of renowned management consultant, W. Edwards Deming. In the 1950s, Deming convinced Japanese automobile manufacturers that production lines in which workers perform a single, repetitive task are less conducive to quality than those in which teams of workers cooperate and take responsibility for the product as a whole. In the latter case, says MacIntyre, the

ends informing the workers' activity are now those of achieving through shared deliberation and decision the making of an excellent car and of becoming excellent in making such cars. It matters that they understand what they are doing and that their standards are ones that they have made their own, not standards imposed by external managerial control. They share direction toward a common good. (2016, pp.170-171)

While Deming would not frame his thought in the language of common goods, what is notable from the perspective of attempting to apply MacIntyre's work to business ethics is the fact that MacIntyre remains alive to the ways in which relatively achievable improvements to work can contribute to our flourishing, even as he keeps the ways in which most work frustrates that flourishing clearly in view.

\section{References}

Bernacchio, C. (2018). Networks of Giving and Receiving in an Organizational Context: Dependent Rational Animals and MacIntyrean Business Ethics. Business Ethics Quarterly 28(4): 377-400.

Couch, R. \& Bernacchio, C. (2020). The virtues of equality and Dissensus: MacIntyre in dialogue with Rancière and Mouffe. Journal of Business Ethics 164(4): 633-642.

Ferrero, I. \& Sison, A. J. G. (2014). A quantitative analysis of authors, schools and themes in virtue ethics articles in business ethics and management journals (1980-2011). Business Ethics: A European Review 23(4): 375-400.

MacIntyre, A. (1979). Social science methodology as the ideology of bureaucratic authority. In Through the looking glass: Epistemology and the conduct of enquiry, ed. M.S. Falco, 4258. Lanham, MD: University Press of America.

MacIntyre, A. (1982). Why Are the Problems of Business Ethics Insoluble? In Moral Responsibility and the Professions, ed. B. Baumrin and B. Friedman, 350-359. Notre Dame, IN: University of Notre Dame Press.

MacIntyre, A. (1999a). Social structures and their threats to moral agency. Philosophy 74(3): 311-329.

MacIntyre, A. (1999b). Dependent Rational Animals: Why Human Beings Need the Virtues. Chicago, IL: Open Court. 
MacIntyre, A. (2007). After Virtue ( $3^{\text {rd }}$ ed.). London: Duckworth.

MacIntyre, A. (2008). How Aristotelianism can become revolutionary: Ethics, resistance, and utopia. Philosophy of Management 7(1): 3-7.

MacIntyre, A. (2015). The Irrelevance of Ethics. In Virtue and economy: Essays on morality and markets, ed. A. Bielskis and K. Knight, 7-21. Farnham: Ashgate.

MacIntyre, A. (2016). Ethics in the Conflicts of Modernity. Cambridge: Cambridge University Press.

Moore, G. (2008). Re-imagining the morality of management: A modern virtue ethics approach. Business Ethics Quarterly 18(4): 483-511.

Moore, G. \& Beadle, R. (2006). In search of organizational virtue in business: Agents, goods, practices, institutions and environments. Organization Studies 27(3): 369-389.

Rocchi, M., Ferrero, I., \& Beadle, R. (2021). Can finance be a virtuous practice? A MacIntyrean account. Business Ethics Quarterly 31(1): 75-105.

Sinnicks, M. (2018). Leadership After Virtue: MacIntyre's Critique of Management Reconsidered. Journal of Business Ethics 147(4): 735-746.

Sinnicks, M. (2021). "We Ought to Eat in Order to Work, Not Vice Versa": MacIntyre, Practices, and the Best Work for Humankind. Journal of Business Ethics 174(2): 263-274. 